\title{
Sustainable marketing strategy under globalization: a comparison between p-KIBS and t-KIBS sectors
}

\author{
Veronika Bumberova ${ }^{1, *}$, Lucie Kanovska ${ }^{2}$ \\ ${ }^{1}$ Brno University of Technology, Faculty of Business and Management, Czech Republic \\ ${ }^{2}$ Brno University of Technology, Faculty of Business and Management, Czech Republic
}

\begin{abstract}
The recognition of the relevance of knowledge-intensive business services (KIBS) is becoming especially acute in the European Union and even more important for many emerging economies. The objective of this paper is to explore what are the differences in marketing strategy to sustain the competitiveness of KIBS in the local and global markets in the last five years. In addition, this research compares what are the differences between the technology-based (t-KIBS) and professionalbased (p-KIBS) business services. The empirical evidence is based on quantitative and firm-level data gathered through an email questionnaire which yielded 128 qualified responses from the small enterprises in Czech Republic. The analysis is based on descriptive statistics and non-parametric tests to compare the differences between the two groups of enterprises. The empirical evidence displays a diversity between t-KIBS and p-KIBS in usage of marketing policy such as pricing policy, brand or company presentation as well as the markets they operate on in the last five years. The research contributions of this study are twofold. First, the results have implications for managers involved in business development of service industry and second, results could be useful for government efforts to support the development (export) activities of KIBS as a heterogeneous category.
\end{abstract}

\section{Introduction}

It is well known, that the knowledge-intensive business services (KIBS) as a small proportion of all services, is significant in terms of economic benefits and as the key part of the growth in value added, employment and labour productivity [1]. The recognition of the relevance of KIBS firms is becoming especially acute in the European Union [2] and even more important for many emerging economies [3, 4]. The empirical analysis of the Visegrad countries conducted by [4] revealed, that despite of just a few years of development of advanced services in Central and Eastern Europe, they already play an important role as advance business providers, however many countries do not reveal much data (out of the V4 countries, only Hungary and Poland provide data such as FDI).

*Corresponding author: bumberova@ $\underline{\text { fbm.vutbr.cz }}$ 
Therefore, aggregate statistics are not useful for long-term analysis or drawing international comparisons. In the Czech Republic, the importance of the manufacturing industry prevails, which is reflected in the relatively lower share of market services and thus the KIBS in the structure of the Czech economy. However, this segment represents a facilitator of knowledge, external information, and an innovation to other business clients from private and public sector especially manufacturing sector [5]. The interconnection between KIBS and the private manufacturing sector contributes to the many benefits of both KIBS and the manufacturing sector in enhancing their competitive edge and innovation [2].

The structure of this paper is as follows. The following section introduces the theoretical framework consisting of sustainable marketing strategy with focus on KIBS sector. The subsequent methodology section provides the details of data collection and analytical methods. The fourth section presents the findings of the analyses. The results are discussed with the aim of answering the proposed research questions. The final section summarizes the conclusions of the study and provides the implications for future research.

\subsection{Sustainability, sustainable marketing strategy and globalization}

In this paper, we define sustainability using the dominant definition established by the World Commission on Environment and Development (WCED): "Sustainable development means meeting the needs of the present without compromising the ability of future generations to meet their own needs." This business definition mean that firms engaged in sustainability need to seek strategies that simultaneously create economic value into future.

As institutions such as OECD or Eurostat suggest, the sustainable marketing strategies involving innovations and significant changes in design, placement, promotion or pricing. These strategies lead to tactical marketing actions such as changes in sales or distribution methods, advertising or permanent exhibitions. The objective is to increase appeal for the firms' products and/or to enter new markets. These actions focus on customer's needs, opening new markets, or repositioning a company's product with the intent to increase sales. Firms focusing on marketing actions are likely to have a better ability to increase customer satisfaction, also to successfully adapt to changing market needs, to discover and exploit business opportunities and to access new information and resources in order to develop new competitive products or processes.

The main goals of marketing strategies for business leaders are to fill market needs, grow market share, and increase shareholder value [6]. Small business leaders should gather all insights regarding marketing activities to forecast growth and sustainability patterns [7]. Marketing strategy is closely related to marketing mix as combination of four elements: the product planning, the price fixation, distribution system, and promotion to meet the need of targeted market and at the same time used to meet the need of marketing. Product, price, promotion, and place are the traditional 4P concepts in relationship marketing for small business owners to improve its competitive position in the market [8]. Driven marketing approaches involve the initiation of product strategies that foster the development of product positioning, formulation, advertising, and pricing. Changing the product might be necessary to maintain or grow market share because product characteristics are also factors of brand loyalty [9].

According to [10] the firm competitive strategies in terms of distribution, price, reputation and innovativeness appear as the most significant determinants of sustainable development of KIBS. Marketing activities such as marketing communications, personal selling, competition-based pricing, product development, and distribution may help emphasize differentiation-based product market strategies to meet market goals [11]. Marketing new products keeps customers aware of new offerings; for long-term growth 
organizations must involve innovation and insights from customers [12]. Executives use promotion, advertising, fundraising, and public relations as principles of marketing operations and strategy [13].

The localization effects and globalization effects are also manifested in a number of forms which relate to the growth of KIBS. This group of services may be pulled into international markets as a result of the location decisions of their existing clients, and the requirement to follow them as they move to new locations, or they may form part of a push by KIBS firms themselves to enter and exploit opportunities in overseas markets [14]. As [15] argues, the market reach of KIBS often extends well beyond their regional bases to national and international nexuses of "corporate exchange", which is particularly the case for very well-established KIBS such as legal services and accountancy. Globalization and localization effects are generally interconnected, rather than diametric forces [16]. For instance, successful connectivity in global spaces is often the outcome of an initial system of localized interaction, whereby it is the knowledge crossing hallways and streets that initially catalysis intellectual exchange and knowledge transfer across oceans and continents.

\subsubsection{Defining of $p-K I B S$ and $t-K I B S$}

This sector is characterized by private sector of small enterprises with high level of knowledge and orientation of its services to other companies and organizations that are predominantly non-routine [5]. Further, two types of KIBS are usually defined [3] the more traditional professional services (p-KIBS) such as accountancy, legal, management consultancy services and the more technology-based KIBS (t-KIBS) such as computer, engineering, R\&D and testing services etc. Following [1] and [10] are KIBS further divided as technology and professional according aggregated subsectors (see Table 1).

Table 1. Classification of KIBS activities according to NACE 2

\begin{tabular}{|c|c|c|c|}
\hline NACE Rev. 2 & $\begin{array}{l}\text { Description of } \\
\text { section }\end{array}$ & Description of division & Type \\
\hline Section J, division 62 & \multirow{2}{*}{$\begin{array}{l}\text { Information and } \\
\text { Communication } \\
\text { activities }\end{array}$} & $\begin{array}{c}\text { Computer programming, consultancy } \\
\text { and related activities }\end{array}$ & $\mathrm{T}$ \\
\hline Section J, division 63 & & Information service activities & $\mathrm{T}$ \\
\hline Section M, division 69 & \multirow{5}{*}{$\begin{array}{l}\text { Professional, } \\
\text { scientific and } \\
\text { technical } \\
\text { activities }\end{array}$} & $\begin{array}{c}\text { Legal, law and accounting, consulting } \\
\text { activities }\end{array}$ & $P$ \\
\hline Section $\mathrm{M}$, division 70 & & $\begin{array}{l}\text { Activities of head offices; management } \\
\text { consultancy activities }\end{array}$ & $\mathrm{P}$ \\
\hline Section $\mathrm{M}$, division 71 & & $\begin{array}{c}\text { Architectural and engineering } \\
\text { activities; technical testing and analysis }\end{array}$ & $\mathrm{T}$ \\
\hline Section M, division 72 & & Scientific research and development & $\mathrm{T}$ \\
\hline Section $M$, division 73 & & Advertising and market research & $\mathrm{P}$ \\
\hline
\end{tabular}

\subsection{Sample and methods}

The research question for the purpose of this research is "Are there differences in marketing development strategy between the technology-based (t-KIBS) and professional KIBS ( $p$ KIBS) according served markets?" From this question there was defined null hypothesis that there are no differences between p-KIBS and t-KIBS and "there is correlation between marketing development strategy with served target markets of KIBS enterprises". 
Primary research was conducted on a sample of small enterprises in the Czech Republic operated in the market. Based on retrospective data over the 5-year period, it has been identified innovation development strategies and related changes within the business. The source of contacts to respondents was the university database Amadeus for which selection criteria were selected:

- Headquarters in the Czech Republic, only private profit sector of market services (limited liability companies, joint stock companies and self-employed).

- The enterprises had to be in operation for more than 5 years and there should not be a presumption of bankruptcy or insolvency.

- The size determined by total number of employees is between 9 and 50 .

- Owner should be a senior executive (CEO) and must be in the top management or in the board of directors and has majority share (50.1\%).

- Classification of economic activity according to NACE 2 (see Table 2).

Table 2. Structure of respondents according to KIBS classification by NACE Rev.2

\begin{tabular}{|c|c|c|c|c|c|}
\hline \multirow{2}{*}{$\begin{array}{c}\text { KIBS by } \\
\text { NACE Rev. 2 }\end{array}$} & \multicolumn{2}{|c|}{ Theoretical } & \multicolumn{2}{c|}{ Empirical } & \multirow{2}{*}{ Type } \\
\cline { 2 - 5 } Section J, 62 & Absolute & Relative & Absolute & Relative & \\
\hline Section J, 63 & 200 & $25,00 \%$ & 37 & $28,90 \%$ & t-KIBS \\
\hline Section M, 69 & 21 & $2,00 \%$ & 3 & $2,30 \%$ & t-KIBS \\
\hline Section M, 70 & 64 & $18,00 \%$ & 19 & $14,80 \%$ & p-KIBS \\
\hline Section M, 71 & 407 & $5,00 \%$ & 7 & $5,50 \%$ & p-KIBS \\
\hline Section M, 72 & 17 & $34,00 \%$ & 40 & $31,30 \%$ & t-KIBS \\
\hline Section M, 73 & 191 & $1,00 \%$ & 4 & $3,10 \%$ & t-KIBS \\
\hline KIBS total & 1214 & $1000 \%$ & 18 & $14,10 \%$ & p-KIBS \\
\hline t-KIBS total & 754 & $62,10 \%$ & 84 & $65,62 \%$ & - \\
\hline p-KIBS total & 469 & $37,90 \%$ & 44 & $34,38 \%$ & - \\
\hline
\end{tabular}

\section{Results and discussion}

We divided a geographical market served by KIBS into five dimensions: local, regional, national, EU member states, outside of EU according their percentage of total sales/turnover. This item was constructed on Likert-scale measure and coded as $0(0 \%), 1$ : $(1-20 \%), 2:(21-40 \%), 3:(41-60 \%), 4:(61-80 \%), 5:(81 \%-100 \%)$. The served markets was recoded into three broad categories as local (regional and local markets), national and international (EU markets and out of EU markets) for evaluating overall level. It is clear from the following Figure 1, that the local and national market within the Czech Republic dominate the small KIBS geographic scope. Nevertheless, the international markets represent important potential for global operations, especially for T-KIBS sector.

In our case, we didn't identify purely "born global" company (focus of operations only on foreign markets). Results suggest, that the highest level of services with operation in the international market are sectors such as computer related activities, engineering and architectural sector. The lowest of percentage of total sales/turnover in international space are related to the services provided being bound by the laws or regulations of the nation/country concerned with the domain of legal, accounting and other activities (close link with government and public procurement). The international nexuses of "corporate exchange ", are particularly the case a well-established and large companies as legal services and accountancy but not for small private companies within KIBS sector. We recognise a considerable share of operations in foreign markets in sectors such as advertising and market research and business management consultancy. 


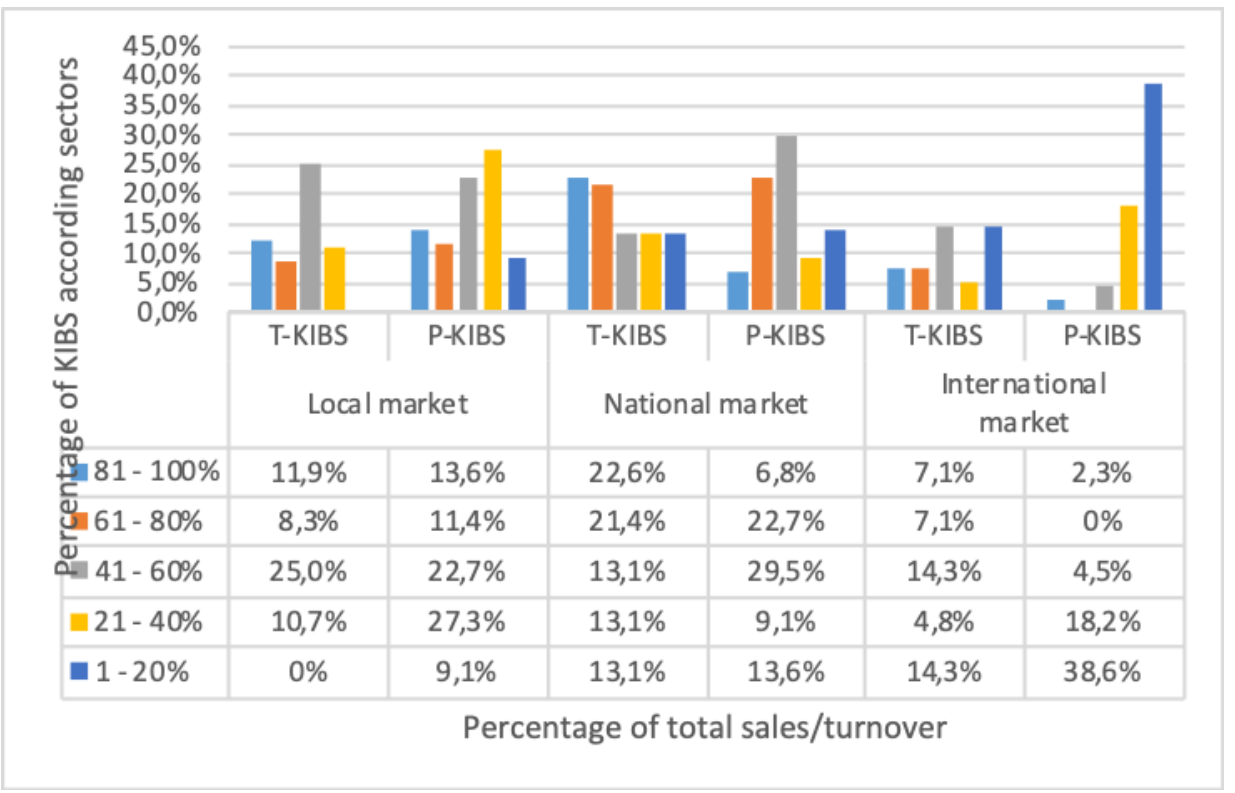

Fig. 1. Served markets by t-KIBS and p-KIBS

Because the data exhibits skewness, which implies departures from normality, the distribution-free non-parametric tests are used to examine whether there exist significant differences. The Mann-Whitney test is used for two group comparisons to test whether there exist significant differences between sectors. The next table 3 show, that there are significant differences with respect to the operations on local $($ Sig. $=0,000)$ and international $($ Sig. $=0,002)$ markets served. Whereas the focus of research has been on KIBS operating in the market at least 5 years, most of them are already well-established and operating across the nation/country.

Table 3. Statistics of non-parametric tests for grouping variable sectors

\begin{tabular}{|c|c|c|c|c|}
\hline $\begin{array}{c}\text { Description of overall index } \\
\text { and individual items } \\
\text { included }\end{array}$ & \multicolumn{4}{|c|}{ Grouping variable sectors: p-KIBS and t-KIBS } \\
\cline { 2 - 5 } & $\begin{array}{c}\text { Mann- } \\
\text { Whitney } \mathrm{U}\end{array}$ & Wilcoxon $\mathrm{W}$ & $\mathrm{Z}$ & Sig. $^{\text {a }}$ \\
\hline Overall level of market served & 1084,500 & 4654,500 & $-3,883$ &, $000^{*}$ \\
\hline Local market & 1127,000 & 4697,000 & $-3,238$ &, $001^{*}$ \\
\hline National market & 1674,000 & 5244,000 &,- 887 &, 375 \\
\hline International markets & 1264,000 & 4750,000 & $-3,035$ &, $002^{* *}$ \\
\hline
\end{tabular}

${ }^{a}$ Asymp. Sig. (2-tailed), * Sig. $\leq 0.05, * *$ Sig. $\leq 0.01$.

Further, we used exploratory factor analysis (PCA with a Varimax rotation) to reduce the number of variables for explanation of marketing development strategy adopted by KIBS. The examination of out-put variables is based on Sum Factors as the average score of multi-item scales. In evaluating the exploratory factor analysis, several criteria are used: the total variance explained $(\geq 0.50)$, the factor loading $(\geq 0.50)$ and the internal consistency was measured with Cronbach's alpha giving results above the critical limit of 0.60 . The items of marketing actions incorporated the changes according to literature review. This item was constructed on Likert-scale measure 1: strongly agree to 5: strongly disagree. As can be seen from table 4, the pattern of loadings suggests that the one factor resolution exist of which together explained $56,53 \%$ of the variance with KMO 0,772. 
Table 4. PCA with Varimax rotation

\begin{tabular}{|c|c|c|c|}
\hline Factor name & Name of the items included & Loadings & $\begin{array}{l}\text { Cronbach' } \\
\text { s alpha }\end{array}$ \\
\hline \multirow{6}{*}{$\begin{array}{c}\text { Marketing } \\
\text { development } \\
\text { strategy }\end{array}$} & $\begin{array}{l}\text { The development required the change in the current } \\
\text { customer segments }\end{array}$ & 0,723 & \multirow{6}{*}{0,754} \\
\hline & $\begin{array}{c}\text { The development required change in company and } \\
\text { product presentation }\end{array}$ & 0,785 & \\
\hline & $\begin{array}{l}\text { The development required the introduction of a new } \\
\text { distribution channels }\end{array}$ & 0,722 & \\
\hline & $\begin{array}{l}\text { The development required the introduction of a new } \\
\text { pricing policy of service offered }\end{array}$ & 0,516 & \\
\hline & $\begin{array}{l}\text { The development required the change in } \\
\text { communication with customers }\end{array}$ & 0,698 & \\
\hline & $\begin{array}{c}\text { The development required change in brand of services } \\
\text { offered }\end{array}$ & 0,738 & \\
\hline
\end{tabular}

The next Table 5 show differences in overall received marketing development strategy (Sig. $=0,022)$ between sectors with significant differences in product presentation $($ Sig. $=0,000)$, price strategy $($ Sig. $=0,002)$ and brand of services offered $($ Sig. $=0,002)$. Product presentation is very important marketing tool in terms of penetration or entering new markets and help to promote brands. Building a valuable brand increases customer value perception, gives the product a higher quality level, increases profitability [17] and lead to the sustainable development of these companies. Companies that have a strong brand name achieve better performance and marketing capabilities [18]. It seems that $\mathrm{T}$ KIBS are more capable implement changes in brand offered on international markets, whereas P-KIBS perceived changes in product presentation on national market.

Table 5. Statistics of non-parametric tests for grouping variable sectors

\begin{tabular}{|c|c|c|c|c|}
\hline $\begin{array}{c}\text { Description of SUM Index } \\
\text { and individual items } \\
\text { included }\end{array}$ & \multicolumn{4}{|c|}{ Grouping variable sectors: p-KIBS and t-KIBS } \\
\cline { 2 - 5 } & $\begin{array}{c}\text { Mann- } \\
\text { Whitney U }\end{array}$ & Wilcoxon W & $\mathrm{Z}$ & Sig. $^{\mathrm{a}}$ \\
\hline $\begin{array}{c}\text { Marketing development } \\
\text { strategy }\end{array}$ & 1394,000 & 4964,000 & $-2,294$ & $0,022^{*}$ \\
\hline Customer segment & 1760,000 & 5330,000 &,- 454 &, 650 \\
\hline Product presentation & 1310,000 & 4880,000 & $-2,783$ &, $005^{*}$ \\
\hline Distribution channels & 1628,000 & 2618,000 & $-1,152$ &, 249 \\
\hline Price strategy & 1130,500 & 4700,500 & $-3,714$ &, $000^{* *}$ \\
\hline $\begin{array}{c}\text { Communication with } \\
\text { customers }\end{array}$ & 1601,500 & 5171,500 & $-1,305$ &, 192 \\
\hline Brand of services offered & 1420,500 & 4990,500 & $-2,324$ &, $020^{*}$ \\
\hline
\end{tabular}

${ }^{a}$ Asymp. Sig. (2-tailed), * Sig. $\leq 0.05, * *$ Sig. $\leq 0.01$.

As table 6 show, there are significant correlation between the markets served and perceived changes in marketing actions. Results show that marketing development strategy correlate with operations on national $(\mathrm{d}=0,18)$ and international markets $(\mathrm{d}=0,22)$. Further, the operations on international markets in the last five year requested the changes in product presentation $(d=0,23)$, distribution channels $(d=0,27)$, communication $(d=0,18)$ and brand of service offered $(\mathrm{d}=0,20)$, whereas, the operations on national market requested the changes only in product presentation/promotion. 
Table 6. Bivariate correlation matrix

\begin{tabular}{|c|c|c|c|c|c|c|c|c|c|c|}
\hline & 1 & 2 & 3 & 4 & 5 & 6 & 7 & 8 & 9 & 10 \\
\hline $\begin{array}{c}1 . \\
\text { Marketing } \\
\text { strategy }\end{array}$ & 1,00 & & & & & & & & & \\
\hline $\begin{array}{l}\text { 2. Customer } \\
\text { segment }\end{array}$ & $0,74 * *$ & 1,00 & & & & & & & & \\
\hline $\begin{array}{l}\text { 3. Product } \\
\text { presentation }\end{array}$ & $0,83 * *$ & $0,43 * *$ & 1,00 & & & & & & & \\
\hline $\begin{array}{c}4 . \\
\text { Distribution } \\
\text { channels }\end{array}$ & $0,53 * *$ & $0,43 * *$ &, $42 * *$ & 1,00 & & & & & & \\
\hline $\begin{array}{l}\text { 5. Price } \\
\text { strategy }\end{array}$ & 0,11 & 0,00 & $0,19 *$ & 0,14 & 1,00 & & & & & \\
\hline 6. Comm. & $0,64 * *$ & $0,33 * *$ & $0,46^{* *}$ & $0,44 * *$ & $-0,02$ & 1,00 & & & & \\
\hline $\begin{array}{l}\text { 7. Brand of } \\
\text { services }\end{array}$ & $0,69 * *$ & $0,47 * *$ & $0,49 * *$ & $0,34 * *$ & $0,21^{*}$ & $0,30 * *$ & 1,00 & & & \\
\hline $\begin{array}{l}\text { 8. Local } \\
\text { market }\end{array}$ & 0,13 & 0,01 & 0,13 & $-0,01$ & $-0,07$ & 0,03 & 0,07 & 1,00 & & \\
\hline $\begin{array}{c}9 . \\
\text { International } \\
\text { markets }\end{array}$ & $0,22 *$ & 0,15 & $0,23 * *$ & $0,27 * *$ & 0,02 & $0,18^{*}$ & $0,20^{*}$ & 0,02 & 1,00 & \\
\hline $\begin{array}{l}\text { 10. National } \\
\text { markets }\end{array}$ & $0,18^{*}$ & 0,05 & $0,31 *$ & $-0,11$ & 0,07 & 0,14 & 0,04 & $0,22 *$ & 0,20 * & 1,00 \\
\hline
\end{tabular}

** Correlation is significant at the 0.01 level (2-tailed), * significant at the 0.05 level (2-tailed)

\section{Conclusions}

Marketing strategies have an effect on financial outcomes for small businesses and lead to the sustainable development of these companies. An effective marketing strategy increased sales and dominance in a targeted market [6]. KIBS managers/owners are tasked with using various communication levels to determine which consumer populations are most likely to talk about a company brand to help influence quantifiable ways to sales and profitability [19]. Executives can use marketing communications to obtain information and advice, offer information about products, and persuade target customers on the merits of a particular product [20].

T-KIBS have more international potential with the ability to implement changes in brand offers to sustain development and competitiveness on global scale. This does not mean that P-KIBS have no global potential, but depends on close interconnection with laws, regulations of the nation/country and close link with government and public procurement (e.g. traditional accounting). The research found a considerable potential of PKIBS in foreign markets in sectors such as advertising and market research and business management consultancy, which are wider usable for commercial purpose, B2B oriented companies. However, the highest level of services with operation in the international market are IT services, engineering and architectural/design sector.

\section{References}

1. M. Freel, Patterns of technological innovation in knowledge-intensive business services. Industry and Innovation 13, 3 (2006) 
2. K. Horváth, R. Rabetino, Knowledge-intensive territorial servitization: regional driving forces and the role of the entrepreneurial ekosystém. Regional Studies 53, 3 (2019)

3. I. Miles, V. Belousova, N. Chichkanov, Innovation Configurations in knowledgeintensive business services. Foresight and STI Governance 11, 3 (2017)

4. A. Klimek, Advanced business services in the global economy and the Visegrád Group economies. International Business and Global Economy 5, 37 (2018)

5. R. Shearmur, D. Doloreux, Exploring Knowledge-Intensive Business Services: Knowledge management strategies (Palgrave Macmillan, London, 193-213, 2012)

6. B. Jemaiyo, An assessment of the effectiveness of marketing strategies adopted by sugar manufacturing companies in Kenya. Journal of Emerging Trends in Economics and Management Sciences 4, 3 (2013)

7. A. M. Fiore, L. S. Niehm, J. L. Hurst, J. Son, A. Sadachar, Entrepreneurial marketing: Scale validation with small, independently-owned businesses. Journal of Marketing Development and Competitiveness 7, 4 (2013)

8. K. Borisavljevic, Relationship marketing: Exploring relational strategies in marketing. Relationship marketing: Ekonomski Horizonti 15, 3 (2013)

9. S. M. P. Schmidt, D. L. Ralph, Marketing vineyards and their regions. The Business Review, Cambridge 22, 1 (2014)

10. N. Corrocher, L. Cusmano, A. Morrison, Modes of innovation in knowledge-intensive business services evidence from Lombardy. Journal of Evolutionary Economics 19, 2 (2009)

11. A. A. Mohammed, B. B. Rashid, S. B. Tahir, Customer relationship management (CRM) Technology and organization performance: is marketing capability a missing link? an empirical study in the malaysian hotel industry. Asian Social Science 10, 9 (2014)

12. P. Barwise, S. Meehan, Customer insights that matter. Journal of Advertising Research 51, 2 (2011)

13. E. Tabaku, Z. M. Mersini, An Overview of Marketing Means used by Non-Profit Organizations: A Detailed Overview of NPOs Operating in the District of Elbasan. Journal of Marketing and Management 5, 1 (2014)

14. M. Miozzo, I. Miles, The relation between the internationalization of services and the process of innovation: a research agenda. Internationalization, technology and services (PREST/CRIC studies in science, technology, and innovation, Edward Elgar Publishing, 15-32, 2002)

15. P. Wood, Urban development and knowledge-intensive business services: Too many unanswered questions? Growth and Change 37, 3 (2006)

16. R. Huggins, The growth of knowledge-intensive business services: Innovation, markets and networks. European Planning Studies 19, 8 (2011)

17. D. Dogramatzis, Biomarketing strategy and tactics 101: Part I of III. Journal of Commercial Biotechnology 18, 3 (2012)

18. M. Jannesari, H. Ghorbani, F. A. Haery, Effects of Managers' Perception of Competition Intensity in the Industry and Marketing Capabilities on the Brand Performance (Computer Services Companies as Case Study). International Journal of Academic Research in Business and Social Sciences 4, 2 (2014)

19. E. Keller, B. Fay, Word-of-mouth advocacy: A new key to advertising effectiveness. Journal of Advertising Research 52, 4 (2012)

20. M. T. Khan, The concept of'marketing mix'and its elements (a conceptual review paper). International Journal of Information, Business and Management 6, 2 (2014) 